\title{
Article
}

\section{Differences in Dietary Patterns of Adolescent Patients with IBD}

\author{
Justyna Kikut ${ }^{1}$, Karolina Skonieczna-Żydecka ${ }^{2}\left(\mathbb{D}\right.$, Diana Sochaczewska ${ }^{3}$, Agnieszka Kordek ${ }^{3}(\mathbb{0}$ \\ and Małgorzata Szczuko $1, *$ (i)
}

1 Department of Human Nutrition and Metabolomics, Pomeranian Medical University in Szczecin, Broniewskiego 24 Street, 71-460 Szczecin, Poland; justyna.kikut@pum.edu.pl

2 Department of Biochemical Sciences, Pomeranian Medical University in Szczecin, Broniewskiego 24 Street, 71-460 Szczecin, Poland; karzyd@pum.edu.pl

3 Department of Neonatology, Pomeranian Medical University in Szczecin, 72-010 Police, Poland; Diana.sochaczewska@pum.edu.pl (D.S.); agkordek@pum.edu.pl (A.K.)

* Correspondence: malgorzata.szczuko@pum.edu.pl; Tel.: +48-91-441-4806

Citation: Kikut, J.;

Skonieczna-Żydecka, K.;

Sochaczewska, D.; Kordek, A.; Szczuko, M. Differences in Dietary Patterns of Adolescent Patients with IBD. Nutrients 2021, 13, 3119.

https://doi.org/10.3390/nu13093119

Academic Editor: Lutz Schomburg

Received: 20 July 2021

Accepted: 29 August 2021

Published: 6 September 2021

Publisher's Note: MDPI stays neutral with regard to jurisdictional claims in published maps and institutional affiliations.

Copyright: (c) 2021 by the authors. Licensee MDPI, Basel, Switzerland. This article is an open access article distributed under the terms and conditions of the Creative Commons Attribution (CC BY) license (https:// creativecommons.org/licenses/by/ $4.0 /)$.
Abstract: Inflammatory bowel disease (IBD) includes Crohn's disease (CD) and ulcerative colitis (UC). The prevalence of both in pediatric populations has been constantly increasing. This study aimed to analyze the diet of adolescent patients with IBD in comparison to healthy controls and the current dietary standards for the Polish population to further their optimal supplementation regimen. The study group consisted of 53 patients (21 girls and 32 boys) with IBD (CD: $n=27 ; \mathrm{UC}: \mathrm{n}=26)$ at a mean age of $15.4 \pm 2.4$ and $14.7 \pm 2.2$, years for girls and boys, respectively. The control group (CG) consisted of 20 patients, and $72 \mathrm{~h}$ of recall diaries on nutrition were collected. The nutritional data were analyzed in the Dieta 6D dietary program. When compared to Polish dietary standards, the largest differences girls with IBD and boys with IBD were found for the intake of energy (61.9 and $71.9 \%$ ), iodine (61.9 and 62.6\%), folates (76.2 and 87.5\%), vitamin D (100 and 96.9\%), potassium (61.9 and $59.4 \%$ ), and calcium ( 85.7 and $93.8 \%$ ). The overconsumption of saturated fatty acids (SFA) (61.9 and $56.3 \%$ ) and sodium (76.2 and $90.6 \%$ ) in girls and boys, respectively, was noted. In relation to girls with CG, girls with IBD showed a significantly higher intake of energy (1751. 3 vs. $1558.6 p=0.0224)$, total protein (71.3 vs. $56.2 p=0.0217)$, animal protein ( 47.8 vs. $34.5 p=0.0183)$, total carbohydrates ( 237.3 vs. $196.1 p=0.0442)$, and assimilable carbohydrates ( 219.8 vs. $180.5 p=0.7921)$. Boys in the CG consumed significantly more calcium (851.8 vs. $432 p=0.0006)$, phosphorus (1024.3 vs. 1357.5 $p=0.0431)$, lactose (11.6 vs. $6.1 p=0.0016)$, and riboflavin (1.7 vs. $1.3 p=0.0123$ ) compared to boys with IBD. Dietician care should therefore be mandatorily provided alongside outpatient care. Based on our results, we suggest that supplementation with the selected components be considered.

Keywords: inflammatory bowel disease; Crohn's disease; ulcerative colitis; diet; nutrition; teenagers; adolescents

\section{Introduction}

Inflammatory bowel disease (IBD) includes Crohn's disease (CD) and Ulcerative Colitis (UC). The disease is characterized by chronic non-infectious inflammation of the gastrointestinal tract (GT) [1]. UC mainly affects the large intestine, whereas CD may involve the entire gastrointestinal tract [2]. UC is defined as an idiopathic, chronic, and recurrent inflammatory disease of the colon. Inflammation of the mucosa in UC extends proximally along the entire colon to include the rectum. The degree of mucosal involvement here determines the course of the disease. Dysregulated immune response of the intestinal mucosa, influenced by the interaction of genetic and environmental factors, is thought to be a predictor of UC $[3,4]$.

Currently, a relevant increase in the prevalence of IBD in children has been noted [5]. The group under 18 years of age represents an estimated 10-15\% of diagnosed patients [2]. A particularly higher incidence rate has been observed in developed countries. Interestingly, a similarly higher incidence rate has been observed in children who emigrate from 
developing countries compared to minors from developed countries [6]. This is related, among other things, to Western diets being characterized by excessive consumption of meat and fat and an insufficient intake of fiber, fruit, and vegetables [7,8]. Excessive intake of trans fatty acids may be associated with systemic inflammation and risk of UC [9]. CD showed an association between excessive intake of total fat, animal-derived fat, and n-6, with a higher incidence of disease [10].

The pathophysiology of IBD is still not completely understood. It has been suggested that the disease occurs in genetically susceptible individuals as a result of an uncontrolled immune system response to a trigger factor [1]. Other factors include environmental factors such as diet or antibiotic use and immunological factors, all of which have been linked to microbiome structure and function disruptions [11,12]. These factors outweigh the genetic ones because genetics alone cannot explain such a significant increase in IBD incidence $[2,5]$.

According to the recommendations of the European Society for Clinical Nutrition and Metabolism (ESPEN), nutritional care is a key component of therapy for patients with IBD. CD patients especially are at a higher risk of developing malnutrition due to the possible involvement of each gastrointestinal tract segment. Moreover, there are no specific nutritional guidelines or recommendations regarding nutrition for individuals with IBD. The diet is usually based on the patient's individual condition [13].

With chronic inflammation and impaired absorption, the risk of deficiencies in micro and macro dietary components increases. Malabsorption is correlated with mucosal function abnormalities such as impaired transport across the epithelium and reduced intestinal barrier integrity [14]. IBD patients make use of a variety of dietary elimination strategies. Up to $70 \%$ of patients continue with elimination diets after remission for fear of re-exacerbating the disease $[15,16]$. Moreover, their relationship with food, i.e., behaviors or beliefs about food, has a major impact on their social life $[15,16]$. On the other hand, other studies show that $57 \%$ of the respondents indicate diet as a predictor of relapse and even $66 \%$ of the patients introduce various types of restrictions in the consumption of favorite products [17]. Similarly, in the Crooks et al. study, 59\% of UC patients shunned their favorite foods for fear of exacerbating their disease, and $23 \%$ of patients followed lactose- and gluten-free diets [18]. Unfortunately, the disadvantage of elimination diets and highly restrictive diets is that they significantly increase the possibility of deficiencies in micro- and macro-components of the diet. Additionally, the variety of proposed dietary recommendations often misleads patients by increasing the use of unnecessary eliminations [19]. Patients with IBD also have food intolerances, predominantly to gluten, lactose, or fructose, which increases the popularity of elimination diets [20,21].

Proper nutrition is particularly important for the proper development of youth. Identifying inappropriate eating habits at an early age can reduce the risk of their repetition into adulthood. An adequate dietary intake of nutrients supports the healing process and an inadequately managed diet can become highly deficient and lead to impaired physical, intellectual, and mental development. In addition, as mentioned above, abnormal attitudes toward eating can negatively impact social competency.

Therefore, the aim of this study was to assess the dietary intake of energy, macro-, and micronutrients by adolescents with IBD compared to Polish reference standards and control group (CG) intake. The study also aimed to identify possible nutritional deficiencies in patients with IBD and to identify components for which supplementation should be considered [22].

A pilot study of ours on IBD and celiac disease has found no significant differences in the nutritional habits between CD and UC. In contrast, differences in nutrition intake between IBD and celiac disease have been shown [23]. Thus, this article analyzes the diets of adolescents with IBD in terms of gender. 


\section{Material and Methods}

\subsection{Study Group (IBD Group)}

The study presents a single-center analysis of the diets of adolescent patients with IBD. The study group included adolescent patients with a mean age of $15.4 \pm 2.4$ years for girls and $14.7 \pm 2.2$ for boys, hospitalized at the Department of Pediatrics, Haemato-Oncology and Pediatric Gastroenterology of the Pomeranian Medical University in Szczecin. Patient recruitment took place from January 2019 to January 2021. The study was approved by the Bioethics Committee of the Pomeranian Medical University (regulation no. KB0012/131/18).

The study group consisted of 73 patients, while 20 patients refused to take part in the study. The study group consisted of 53 patients with IBD, including 27 patients with CD (8 girls and 19 boys) and 26 patients with UC (13 girls and 13 boys). The mean height and body weight were respectively $1.6 \pm 0.1$ and $54.5 \pm 13.9 \mathrm{~kg}$ and for girls and $1.6 \pm 0.2$ and $52.7 \pm 17.7$ for boys. The differences in parameters were not statistically significant ( $p$-values were, respectively $0.929,0.709$ ). The diagnosis of IBD was made based on endoscopic examination (using an Olympus camera) with histopathological evaluation of the intestinal tissue collected during endoscopic examination, which was one of the inclusion criteria for the study. In addition, patients had an ultrasound examination. Whereas in the case of Crohn's disease, enteroclysis or enterography with CT imaging was additionally performed. Patients aged 10 to 18 years with mild to moderate IBD on standard oral nutrition and not specialized elimination diets (e.g., ModuLife, SCD, low FODMAP, vegan, vegetarian) were included in the study. Only patients with lactose intolerance who consumed lactose-free dairy products were included in the study $(n=10)$. Lactose intake was determined by interview and food diaries. Patients reported consuming dairy products without lactose. They did not eliminate dairy from their diet due to lactose intolerance. Exclusion criteria included the use of specialized elimination diets, other food allergies, and age below ten years.

The mean disease duration was 2.5 years in boys and 2.9 years in girls. In the UC and CD group, 19 and 20 patients, respectively, were in remission, and 7 patients were facing a period of disease exacerbation. The degree of disease was determined by a gastroenterologist on the basis of the Pediatric Crohn's Disease Activity Index (PCDAI) Pediatric Ulcerative Colitis Activity Index (PUCAI) questionnaire. Remission of the disease was established by the attending physician through biochemical parameters of inflammation (erythrocyte sedimentation rate (ESR), C-reactive protein (CRP), fecal calprotectin). Patients were taking the following groups of drugs: corticosteroids $(n=12)$, immunosuppressants $(n=25)$, aminosalicylic acid medications $(n=42)$, and biological treatment $(n=2)$. Most patients maintained the habits acquired during disease exacerbations even after going into remission; therefore, their diets did not differ between periods. Among girls, $47.6 \%$ took vitamin D supplements (including 50\% with CD and $46.2 \%$ with UC), $9.5 \%$ supplemented with a multivitamin complex (including $12.5 \%$ with $\mathrm{CD}$ and $7.7 \%$ with UC). Referring to minerals, $23.8 \%$ supplemented calcium (including 50\% with CD and $7.7 \%$ with UC) and $9.5 \%$ of girls supplemented potassium. Among girls, only $15.4 \%$ of UC girls were taking iron supplements. In turn, in the boys' group, vitamin D supplementation was taken by $75 \%$ (including $78.9 \%$ with CD and $69.2 \%$ with UC), vitamin complex by $9.4 \%$ ( $10.5 \%$ with $\mathrm{CD}$ and $7.7 \%$ with UC). Referring to minerals, calcium was supplemented by $25 \%$ of boys ( $21.1 \%$ from $\mathrm{CD}$ and $30.8 \%$ from UC), potassium by $15.6 \%$ (21.1\% from $\mathrm{CD}$ and $7.7 \%$ from UC), iron by $6.3 \%$ ( $5.3 \%$ from CD, $7.7 \%$ from UC). Magnesium was supplemented by only $10.5 \%$ of boys with CD. Supplementation is not included in the daily intake.

\subsection{Control Group (CG)}

The control group was recruited randomly from age- and gender-matched healthy children from the local community in the winter of 2020/2021. General information about the study and its objectives was advertised via social media and paper flyers. Parent's communicated their children's willingness to participate by phone. During the telephone 
calls, it was confirmed that participating children met the following criteria: no changes in dietary habits in the three months prior to the study, including use of elimination diets; no chronic diseases, especially concerning the gastrointestinal tract; and no food intolerances or allergies. Overall, 32 parents gave consent for their children to take part in the study, but at last 20 children came for a face-to-face interview. The control group consisted of 10 girls and 10 boys, aged $14.3 \pm 2.7$ and $14 \pm 3.2$ years, respectively. The mean height and body weight were, respectively, $1.6 \pm 0.1$ and $51 \pm 10.3 \mathrm{~kg}$ for girls, and $1.7 \pm 0.1$ and $52 \pm 12.3$ for boys. The differences in these parameters were not statistically significant ( $p$-values were $0.342,0.614$, respectively).

Anthropometric measurements such as body weight $( \pm 0.1 \mathrm{~kg})$ and height $( \pm 0.5 \mathrm{~cm})$ were used to assess differences in the nutritional status of patients. A medical scale (Radwag WPT $60 / 150$ OW, Poland) with a height gauge was used.

\subsection{Diet Content Analysis}

Dietary patterns were assessed based on recalled nutritional diaries of the $72 \mathrm{~h}$ prior to the assessment. The dietary interview was conducted by a qualified nutritionist. An album of products and meal photos was used to ensure the collection of reliable information regarding the size of the consumed meals [24]. Attempts were made to rule out recall error by using an album of products and meals photos and the record of each day's food diary was verified by a dietitian in the presence of the patient/guardian. A total of 219 children's nutritional diaries were analyzed, of which 159 were from children with IBD and 60 were from healthy children. The Dieta 6D software, recommended by the National Centre of Nutritional Education (Warsaw, Poland), was used for quantitative analysis. The program includes 58 micro- and macro-nutrients, including carbohydrates, fats and fatty acids, and animal and vegetable proteins, with 18 amino acids, 10 minerals, and 10 vitamins, as well as dietary energy, fiber, and cholesterol. The obtained data were compared with the current nutrition standards for the Polish population and with the control group [25].

\subsection{The Comparison with Current Nutrition Standards}

The results obtained were compared with the current nutrition standards for the Polish population. The norms were used according to the average age for both genders, respectively. The results were related to the estimated average requirement (EAR), or if this was not established to the adequate intake (AI).The reference of intake levels to norms is presented with a $\pm 10 \%$ margin. The mean age of $13-15$ years for girls and boys, respectively, was taken as the reference point for nutritional standards. To compare energy intake to norms, the average body mass and average age of the study group were used for boys and girls, respectively. All patients in the study group had low physical activity limited to a maximum of $2-4 \mathrm{~h}$ per week, which was also contributed to by the current epidemiological situation. The average activity of the group was set at a physical activity level of 1.50 for girls and 1.55 for boys.

\subsection{Statistical Analysis}

Statistical analysis was performed using Statistica 13.3 software (Statsoft, Krakow, Poland). The distribution of the continuous data was tested using the Shapiro-Wilk test. Since most data in the study group did not differ significantly from the normal distribution, the analysis within the studied group was carried out using a parametric $t$-student-test. The non-parametric Mann-Whitney test was used to compare the intake of nutrients between the study and control groups. Statistical significance was established at a two-tailed value of $p \leq 0.05$. Post hoc test power analysis was performed using G Power software (Dusseldorf, Germany). The power of tests showed statistical significance above 0.8 . 


\section{Results}

\section{The Quantitative Analysis of the Menus}

Table $1 \mathrm{~A}-\mathrm{C}$ show the percentage of consumption of ingredients for girls and boys with IBD compared to dietary standards. Both boys and girls in the vast majority of the population had deficient intakes of energy, vitamin $\mathrm{D}$, potassium, calcium, magnesium, iodine, and folate. In addition, boys with IBD showed a low intake of vitamins A, E, B1, and vitamin $C$, as well as fiber. Other components were consumed at adequate levels by most of the IBD group in our study. It is important to note that none of the nutrients' single intake values exceeded the upper level (UL) relative to dietary standards [25] and the European Food Safety Authority (EFSA) [26].

Table 1. The percentage of girls and boys in the study group among whom the intake of nutrients deviates from accepted nutritional standards [\%].

\begin{tabular}{|c|c|c|c|c|c|c|}
\hline \multicolumn{7}{|c|}{ A. The percentage of girls and boys with reference to the EAR norm. } \\
\hline \multirow{2}{*}{ Constituent } & \multicolumn{4}{|c|}{$\%$ of girls } & \multicolumn{2}{|c|}{$\%$ of boys } \\
\hline & $<$ EAR & norm & $>$ EAR & $<$ EAR & norm & $>$ EAR \\
\hline Protein $(g)$ & 4.8 & 49 & 46.2 & 3.1 & 15.6 & 81.3 \\
\hline $\mathrm{P}(\mathrm{mg})$ & 14.3 & 33.3 & 52.4 & 37.5 & 15.6 & 46.9 \\
\hline $\mathrm{Mg}(\mathrm{mg})$ & 57.1 & 19.1 & 23.8 & 78.1 & 9.4 & 12.5 \\
\hline $\mathrm{Zn}(\mathrm{mg})$ & 9.5 & 42.9 & 47.6 & 34.4 & 25 & 40.6 \\
\hline $\mathrm{Cu}(\mathrm{mg})$ & 9.5 & 14.3 & 76.2 & 15.6 & 15.6 & 68.8 \\
\hline Iodine $(\mu \mathrm{g})$ & 61.9 & 9.5 & 28.6 & 62.5 & - & 37.5 \\
\hline Vitamin A ( $\mu \mathrm{g})$ & 14.3 & 19 & 66.7 & 46.9 & 6.2 & 46.9 \\
\hline Vitamin B1 (mg) & 28.6 & 23.8 & 47.6 & 40.6 & 15.6 & 43.8 \\
\hline Vitamin B2 (mg) & 4.8 & 4.7 & 90.5 & 31.3 & 18.7 & 50 \\
\hline Niacin (mg) & 23.8 & 9.5 & 66.7 & 21.9 & 3.1 & 75 \\
\hline Vitamin B6 (mg) & - & 19 & 81.0 & 12.5 & 12.5 & 75 \\
\hline Folates $(\mu \mathrm{g})$ & 76.2 & 4.8 & 19 & 87.5 & 9.4 & 3.1 \\
\hline Vitamin B12 $(\mu \mathrm{g})$ & 14.3 & 19 & 66.7 & 37.5 & 18.7 & 43.8 \\
\hline Vitamin C (mg) & 14.3 & 19 & 66.7 & 53.1 & 6.3 & 40.6 \\
\hline
\end{tabular}

B. The percentage of girls and boys with reference to the AI norm.

\begin{tabular}{|c|c|c|c|c|c|c|}
\hline \multirow{2}{*}{ Constituent } & \multicolumn{4}{|c|}{$\%$ of girls } & \multicolumn{2}{|c|}{$\%$ of boys } \\
\hline & $<\mathrm{AI}$ & norm & $>\mathrm{AI}$ & $<\mathrm{AI}$ & norm & $>\mathrm{AI}$ \\
\hline $\mathrm{Na}(\mathrm{mg})$ & 9.5 & 14.3 & 76.2 & - & 9.4 & 90.6 \\
\hline $\mathrm{K}(\mathrm{mg})$ & 61.9 & 19.1 & 19 & 59.4 & 12.5 & 28.1 \\
\hline $\mathrm{Ca}(\mathrm{mg})$ & 85.7 & 4.8 & 9.5 & 93.7 & - & 6.3 \\
\hline $\mathrm{Fe}(\mathrm{mg})$ & 19 & 14.3 & 66.7 & 28.1 & 12.5 & 59.4 \\
\hline Manganese (mg) & - & 14.3 & 85.7 & 25 & 15.6 & 59.4 \\
\hline Vitamin D $(\mu \mathrm{g})$ & 100 & - & - & 96.9 & 3.1 & - \\
\hline Vitamin E (mg) & 28.6 & 38.1 & 33.3 & 65.6 & 12.5 & 21.9 \\
\hline \multicolumn{7}{|c|}{ C. The percentage of girls and boys with reference to nutritional norms. } \\
\hline \multirow{2}{*}{ Constituent } & \multicolumn{4}{|c|}{$\%$ of girls } & \multicolumn{2}{|c|}{$\%$ of boys } \\
\hline & $<$ norm & norm & $>$ norm & $<$ norm & norm & $>$ norm \\
\hline Energy (kcal) & 61.9 & 33.3 & 4.8 & 71.9 & 21.8 & 6.3 \\
\hline Protein $(\%)$ & 4.8 & 19.1 & 14.3 & 2.9 & 97.1 & - \\
\hline Fat (\%) & - & 85.7 & 14.3 & 5.9 & 94.1 & - \\
\hline SFA (g) & - & 38.1 & 61.9 & - & 43.7 & 56.3 \\
\hline Carbohydrates (\%) & 4.8 & 95.2 & - & 2.9 & 91.2 & 5.9 \\
\hline Saccharose $(\mathrm{g})$ & - & 61.9 & 38.1 & - & 81.2 & 18.8 \\
\hline Dietary fiber (g) & 38.1 & 19 & 42.9 & 62.5 & 12.5 & 25 \\
\hline
\end{tabular}

EAR—Estimated average requirement, AI—Adequate intake, SFA—Saturated fatty acids.

Table 2 shows the average intake of nutrients such as protein including particular amino acids and carbohydrates, fat, and cholesterol. The nutrient intake in IBD and CG 
groups of children was analyzed. As for the comparisons between IBD individuals and CG, the results are presented in Table 2 .

Table 2. The comparison of mean nutrient consumption (proteins, fats, and carbohydrates) in IBD and CG by gender.

\begin{tabular}{|c|c|c|c|c|c|c|c|c|c|}
\hline Constituents & Norm & $\begin{array}{l}\text { Girls (IBD) } \\
\text { Avg } \pm \text { SD }\end{array}$ & $\begin{array}{l}\text { Girls (CG) } \\
\text { Avg } \pm \text { SD }\end{array}$ & $\begin{array}{c}p \text { Value } \\
\text { Girls } \\
\text { (IBD) vs. } \\
\text { Girls (CG) }\end{array}$ & $\begin{array}{l}\text { Boys (IBD) } \\
\text { Avg } \pm \text { SD }\end{array}$ & $\begin{array}{l}\text { Boys (CG) } \\
\text { Avg } \pm \text { SD }\end{array}$ & $\begin{array}{c}p \text { Value } \\
\text { Boys (IBD) } \\
\text { vs. Boys } \\
\text { (CG) }\end{array}$ & $\begin{array}{c}p \text { Value } \\
\text { Girls } \\
\text { (IBD) vs. } \\
\text { Boys (IBD) }\end{array}$ & $\begin{array}{c}p \text { Value } \\
\text { Girls (CG) } \\
\text { vs. Boys } \\
\text { (CG) }\end{array}$ \\
\hline $\begin{array}{l}\text { Energy } \\
(\text { kcal })\end{array}$ & $2100 / 2600 *$ & $1751.3 \pm 334.6$ & $1558.6 \pm 505.3$ & 0.0224 & $1892.3 \pm 590$ & $1943.6 \pm 616.9$ & NS & NS & 0.0113 \\
\hline $\begin{array}{l}\text { Total } \\
\text { proteins }\end{array}$ & $\begin{array}{l}0.84 \mathrm{~g} / \mathrm{kg} \\
(43 / 45 * \mathrm{~g})\end{array}$ & $71.3 \pm 20.1$ & $56.2 \pm 21.7$ & 0.0217 & $1032.6 \pm 535.8$ & $85.8 \pm 32.5$ & NS & NS & 0.0091 \\
\hline $\begin{array}{l}\text { Animal } \\
\text { protein }(\mathrm{g})\end{array}$ & - & $47.8 \pm 17.4$ & $34.5 \pm 17.4$ & 0.0183 & $72.8 \pm 26.2$ & $59.7 \pm 29.8$ & NS & NS & 0.0058 \\
\hline $\begin{array}{l}\text { Plant protein } \\
\text { (g) }\end{array}$ & - & $21.9 \pm 6.1$ & $21 \pm 9.2$ & NS & $47.1 \pm 22.4$ & $24.7 \pm 12.1$ & NS & NS & NS \\
\hline $\begin{array}{l}\% \text { energy } \\
\text { from protein }\end{array}$ & $10-20$ & $16.4 \pm 3.8$ & $15.7 \pm 3.7$ & NS & $15.5 \pm 3.4$ & $17.9 \pm 5.4$ & NS & NS & NS \\
\hline Fat $(\mathrm{g})$ & $47-82 / 58-101$ * & $62.7 \pm 17.6$ & $53.3 \pm 22.5$ & NS & $62.5 \pm 30.4$ & $69.8 \pm 28.4$ & NS & NS & NS \\
\hline NKT (g) & $\begin{array}{l}13.6-16.3 / \\
16.8-20.1 \text { * }\end{array}$ & $23.3 \pm 10$ & $20.5 \pm 11.4$ & NS & $26.1 \pm 13.3$ & $28 \pm 15.6$ & NS & NS & 0.0452 \\
\hline $\begin{array}{l}\text { MUFA (g) } \\
\text { PUFA (g) }\end{array}$ & $\begin{array}{l}- \\
-\end{array}$ & $\begin{array}{l}23.3 \pm 7.3 \\
10.5 \pm 5.8\end{array}$ & $\begin{array}{c}20.9 \pm 8.9 \\
7.8 \pm 4.6\end{array}$ & $\begin{array}{l}\text { NS } \\
\text { NS }\end{array}$ & $\begin{array}{c}13.8 \pm 4.9 \\
7.8 \pm 4.9\end{array}$ & $\begin{array}{c}26.3 \pm 10.5 \\
10 \pm 5\end{array}$ & $\begin{array}{l}\text { NS } \\
\text { NS }\end{array}$ & $\begin{array}{l}\text { NS } \\
\text { NS }\end{array}$ & $\begin{array}{l}\text { NS } \\
\text { NS }\end{array}$ \\
\hline $\begin{array}{c}\text { MUFA/ } \\
\text { PUFA [\%] }\end{array}$ & - & $12 / 5.4$ & $12.1 / 4.6$ & NS & $6.6 / 3.8$ & $12.1 / 4.6$ & NS & NS & NS \\
\hline LCP $(\mathrm{g})$ & - & $0.1 \pm 0$ & $0 \pm 0.1$ & NS & $0.1 \pm 0.4$ & $0.2 \pm 0.5$ & NS & NS & NS \\
\hline $\begin{array}{c}\text { Cholesterol } \\
(\mathrm{mg})\end{array}$ & - & $239.7 \pm 132.2$ & $205.4 \pm 137.5$ & NS & $317.8 \pm 247.9$ & $307.9 \pm 216.8$ & NS & NS & 0.0452 \\
\hline $\begin{array}{l}\% \text { energy } \\
\text { from fat }\end{array}$ & $20-35$ & $31.9 \pm 7$ & $31.8 \pm 7.9$ & NS & $28.2 \pm 8.3$ & $31.8 \pm 6.1$ & NS & NS & NS \\
\hline $\begin{array}{l}\text { Total carbo- } \\
\text { hydrates } \\
(\mathrm{g})\end{array}$ & - & $237.3 \pm 61.2$ & $196.1 \pm 75$ & 0.0442 & $268.6 \pm 79.5$ & $251.4 \pm 89.4$ & NS & NS & 0.0312 \\
\hline $\begin{array}{l}\text { Assimilable } \\
\text { carbohy- } \\
\text { drates } \\
\text { (g) }\end{array}$ & - & $219.8 \pm 58.5$ & $180.5 \pm 69.6$ & 0.7921 & $252.7 \pm 76.3$ & $233.9 \pm 83.8$ & NS & NS & 0.0173 \\
\hline $\begin{array}{l}\text { Dietary fiber } \\
(\mathrm{g})\end{array}$ & 19 & $17.6 \pm 7$ & $15.7 \pm 7.5$ & NS & $15.6 \pm 6.3$ & $17.5 \pm 9.7$ & NS & NS & NS \\
\hline $\begin{array}{l}\text { Saccharose } \\
\text { (g) }\end{array}$ & $52.5 / 65 *$ & $48.3 \pm 32.5$ & $29.5 \pm 18.1$ & NS & $52.8 \pm 42.7$ & $44.8 \pm 25$ & NS & NS & 0.0376 \\
\hline Lactose (g) & - & $6.2 \pm 5.6$ & $7.2 \pm 7.2$ & NS & $6.1 \pm 6.2$ & $11.6 \pm 10$ & 0.0016 & NS & 0.0312 \\
\hline $\begin{array}{l}\text { Starch }(g) \\
\% \text { energy }\end{array}$ & - & $110.7 \pm 30.4$ & $106.8 \pm 43.5$ & NS & $150.8 \pm 51.9$ & $132 \pm 58.5$ & NS & 0.0029 & NS \\
\hline $\begin{array}{l}\text { from carbo- } \\
\text { hydrates }\end{array}$ & $45-65$ & $50.6 \pm 8.1$ & $50.4 \pm 8$ & NS & $55 \pm 9.3$ & $48.5 \pm 7.8$ & NS & NS & NS \\
\hline
\end{tabular}

IBD—Inflammatory bowel diseases; CG—control group; * girls/boys; \# \% of intake in relation to total energy content of the diet; NS-non statistically significant.

An energy deficit was statistically significant in both CG and IBD groups. Girls in the study group, in relation to girls in the control group, showed a significantly higher intake of energy (1751. 3 vs. $1558.6 p=0.0224)$, total protein (71.3 vs. $56.2 p=0.0217)$, and animal protein $(47.8$ vs. $34.5 p=0.0183)$. Thus, statistical significance was shown between girls in the intake of most amino acids (Supplement). Protein intake was at an adequate level in both groups. The ratio of animal protein to plant protein in the girls group exceeded 2:1, while in the boys' group it oscillated around 2:1. Girls in the study group had a significantly higher intake of total carbohydrates (237.3 vs. $196.1 p=0.0442$ ) and assimilable carbohydrates ( 219.8 vs. $180.5 p=0.7921)$ compared to girls in the control group. In contrast, boys with IBD showed a higher percentage of dietary carbohydrate intake relative to boys in the control group ( 55 vs. 48.5). Fat intake in both groups was at an adequate level. Intake of saturated fatty acids was excessive for both groups. Mean dietary carbohydrate intake was at normal levels in both groups. Additionally, in the study group, boys consumed significantly more starch than girls (150.8 vs. $110.7 p=0.0029)$.

Saccharose intake did not exceed $10 \%$ of the dietary caloric intake in both groups relative to the mean. However, higher saccharose intake was observed in the IBD group relative to the control group. There was also a significantly lower intake of lactose in the IBD group of boys relative to the CG of boys ( 6.1 vs. $11.6 p=0.0016)$.

The mean fiber intake in both IBD and CG groups was below the accepted norm and did not differ significantly between them. 
Table 3 shows the intake of vitamins. Significant statistical differences were observed in vitamin B6 (1.9 vs. $1.3 p=0.0199)$ and niacin (18.9 vs. $12.2 p=0.0047)$ intake between girls (IBD vs. CG). In contrast, in boys, significant differences were found for riboflavin (1.3 vs. $1.7 p=0.0123$ ) (IBD vs. CG). A statistically significant difference in vitamin C (112.5 vs. $100.7 p=0.0356$ ) intake (girls IBD vs. boys IBD) was observed in the study group.

Table 3. A comparison of vitamin consumption.

\begin{tabular}{|c|c|c|c|c|c|c|c|c|c|}
\hline Constituents & EAR Norm & $\begin{array}{l}\text { Girls (IBD) } \\
\text { Avg } \pm \text { SD }\end{array}$ & $\begin{array}{l}\text { Girls (CG) } \\
\text { Avg } \pm \text { SD }\end{array}$ & $\begin{array}{c}p \text { Value } \\
\text { Girls (IBD) } \\
\text { vs. Girls } \\
\text { (CG) }\end{array}$ & $\begin{array}{l}\text { Boys (IBD) } \\
\text { Avg } \pm \text { SD }\end{array}$ & $\begin{array}{l}\text { Boys (CG) } \\
\text { Avg } \pm \text { SD }\end{array}$ & $\begin{array}{c}p \text { Value } \\
\text { Boys (IBD) } \\
\text { vs. Boys } \\
\text { (CG) }\end{array}$ & $\begin{array}{c}p \text { Value } \\
\text { Girls } \\
\text { (IBD) vs. } \\
\text { Boys (IBD) }\end{array}$ & $\begin{array}{c}p \text { Value } \\
\text { Girls (CG) } \\
\text { vs. Boys } \\
\text { (CG) }\end{array}$ \\
\hline $\begin{array}{l}\text { Vitamin A } \\
(\mu g)\end{array}$ & $490 / 630 *$ & $971.3 \pm 923.8$ & $887.9 \pm 588.1$ & NS & $1068.2 \pm 1059.8$ & $943.9 \pm 494.8$ & NS & NS & NS \\
\hline $\begin{array}{c}\text { Retinol } \\
(\mu g)\end{array}$ & - & $287.8 \pm 207.2$ & $306.4 \pm 177.6$ & NS & $463.6 \pm 696.3$ & $347.4 \pm 231.2$ & NS & NS & NS \\
\hline $\begin{array}{l}\text { Beta } \\
\text { carotene } \\
(\mu \mathrm{g})\end{array}$ & - & $4009.1 \pm 5568.1$ & $3482.2 \pm 3442.7$ & NS & $3579.6 \pm 4209.9$ & $\begin{array}{c}3592.8 \pm \\
2689.6\end{array}$ & NS & NS & NS \\
\hline $\begin{array}{l}\text { Vitamin E } \\
(\mathrm{mg})\end{array}$ & $8 * * / 10 *$ & $8.7 \pm 3.4$ & $13.5 \pm 33.8$ & NS & $6.9 \pm 3.9$ & $9.3 \pm 5.1$ & NS & NS & NS \\
\hline $\begin{array}{l}\text { Thiamine } \\
\text { (mg) }\end{array}$ & $0.9 / 1$ * & $1.1 \pm 0.5$ & $0.9 \pm 0.6$ & NS & $1.1 \pm 0.6$ & $1.3 \pm 0.5$ & NS & NS & 0.0452 \\
\hline $\begin{array}{l}\text { Riboflavin } \\
\text { (mg) }\end{array}$ & $0.9 / 1.1$ * & 0.9 & $1.4 \pm 0.5$ & $1.3 \pm 0.7$ & $1.3 \pm 0.6$ & $1.7 \pm 0.7$ & 0.0123 & NS & 0.0173 \\
\hline Niacin (mg) & $11 / 12 *$ & $18.9 \pm 12.4$ & $12.2 \pm 9.7$ & 0.0047 & $17.3 \pm 9.7$ & $19.7 \pm 11.3$ & NS & NS & NS \\
\hline $\begin{array}{c}\text { Vitamin } \mathrm{B} 6 \\
(\mathrm{mg})\end{array}$ & $1 / 1.1$ * & $1.9 \pm 1$ & $1.3 \pm 0.7$ & 0.0199 & $1.7 \pm 0.8$ & $1.9 \pm 0.7$ & NS & NS & 0.0211 \\
\hline$\underset{(\mathrm{mg})}{\operatorname{Vitamin}} \mathrm{C}$ & $55 / 65^{*}$ & $112.5 \pm 118.6$ & $100.7 \pm 92.8$ & NS & $71.5 \pm 71.8$ & $99.6 \pm 98.7$ & NS & 0.0356 & NS \\
\hline $\begin{array}{l}\text { Vitamin } \\
\text { B12 }(\mu \mathrm{g})\end{array}$ & 2 & $2.5 \pm 0.8$ & $2.5 \pm 1.3$ & NS & $2.6 \pm 1.8$ & $3.6 \pm 1.6$ & NS & NS & 0.0096 \\
\hline $\begin{array}{l}\text { Vitamin D } \\
(\mu \mathrm{g})\end{array}$ & $15^{* *}$ & $1.4 \pm 0.9$ & $1.6 \pm 1.6$ & NS & $2.1 \pm 2.2$ & $3.1 \pm 3.2$ & NS & NS & NS \\
\hline $\begin{array}{c}\text { Folates } \\
(\mu g)\end{array}$ & 330 & $245.5 \pm 135.5$ & $220.2 \pm 92.7$ & NS & $202.5 \pm 86$ & $244.3 \pm 107.2$ & NS & NS & NS \\
\hline
\end{tabular}

IBD—Inflammatory bowel diseases; CG—control group; * girls/boys; ${ }^{* *}$ AI norm; NS—non statistically significant.

None of the genders in both IBD and CG groups achieved the required levels of vitamin D and folate intake. Inadequate intake of vitamin D in the group affected $100 \%$ of girls and $96.9 \%$ of boys, and in both cases was at critically low levels of $1.4 \pm 0.9 \mu \mathrm{g}$ and $3.1 \pm 3.2 \mu \mathrm{g}$, respectively. Adequate intake of vitamins such as vitamin A, B1, B2, B3, B6, $B 12$ and $C$ were observed in both the study and control groups. Both boys in the study and control groups showed insufficient intake of vitamin E, which was not observed in the group of girls.

Regarding the mineral components presented in Table 4, the sodium intake was significantly exceeded in both groups, and higher sodium intake was found among boys at a statistically significant level compared to girls (2927.9 vs. $2447 p=0.0367)$ (IBD vs. IBD). Intake of iron, copper, and manganese met the norms in both groups. Girls with IBD consumed significantly higher amounts of manganese ( 4 vs. $2.4 p=0.0447)$, potassium ( 2588.5 vs. $2054 p=0.0416$ ), and phosphorus (1167.1 vs. $933.4 p=0.0345$ ) compared to girls in the control group. Insufficient intake of potassium, magnesium, and calcium was found in both the control and study groups. Also, boys in the control group consumed significantly more calcium (851.8 vs. $432 p=0.0006)$ and phosphorus (1357.5 vs. 1024.3 $p=0.0431$ ) compared to boys with IBD. The highest deficiency among mineral components was observed in calcium, potassium, and magnesium. Potassium deficiency was higher in the girls' group, while magnesium deficiency was higher in the boys' group. Mean zinc intake was insufficient in the boys' group (IBD). Insufficient intake of iodine, which was not observed in the boys, was observed in both the study and control group of girls. 
Table 4. A comparison of mineral consumption levels.

\begin{tabular}{|c|c|c|c|c|c|c|c|c|c|}
\hline Minerals & EAR Norm & $\begin{array}{l}\text { Girls (IBD) } \\
\text { Avg } \pm \text { SD }\end{array}$ & $\begin{array}{l}\text { Girls (CG) } \\
\text { Avg } \pm \text { SD }\end{array}$ & $\begin{array}{c}p \text { Value } \\
\text { Girls } \\
\text { (IBD) vs. } \\
\text { Girls (CG) }\end{array}$ & $\begin{array}{l}\text { Boys (IBD) } \\
\text { Avg } \pm \text { SD }\end{array}$ & $\begin{array}{c}\text { Boys (CG) Avg } \\
\pm \text { SD }\end{array}$ & $\begin{array}{c}p \text { Value } \\
\text { Boys (IBD) } \\
\text { vs. Boys } \\
\text { (CG) }\end{array}$ & $\begin{array}{c}p \text { Value } \\
\text { Girls } \\
\text { (IBD) vs. } \\
\text { Boys (IBD) }\end{array}$ & $\begin{array}{c}p \text { Value } \\
\text { Girls (CG) } \\
\text { vs. Boys } \\
\text { (CG) }\end{array}$ \\
\hline $\begin{array}{c}\text { Sodium } \\
\text { (mg) }\end{array}$ & $1500 * *$ & $2447 \pm 1089.7$ & $2258.6 \pm 1119.4$ & NS & $2927.9 \pm 1375.5$ & $3156.8 \pm 1393.5$ & NS & 0.0367 & NS \\
\hline $\begin{array}{l}\text { Potassium } \\
(\mathrm{mg})\end{array}$ & $3000 * *$ & $2588.5 \pm 992.9$ & $2054 \pm 952$ & 0.0416 & $2494.7 \pm 983.9$ & $2913.8 \pm 1053.5$ & NS & NS & NS \\
\hline $\begin{array}{l}\text { Calcium } \\
(\mathrm{mg})\end{array}$ & 1100 ** & $592.8 \pm 284.3$ & $619.8 \pm 356.3$ & NS & $432 \pm 267.4$ & $851.8 \pm 516$ & 0.0006 & NS & 0.0376 \\
\hline $\begin{array}{c}\text { Phosphorus } \\
\text { (mg) }\end{array}$ & 1050 & $1167.1 \pm 316.6$ & $933.4 \pm 377.6$ & 0.0345 & $1024.3 \pm 410.2$ & $1357.5 \pm 451.7$ & 0.0431 & NS & 0.014 \\
\hline $\begin{array}{l}\text { Magnesium } \\
(\mathrm{mg})\end{array}$ & $300 / 340 *$ & $261.2 \pm 96.9$ & $205.9 \pm 92.3$ & NS & $232.2 \pm 108.5$ & $293.1 \pm 117.5$ & NS & NS & NS \\
\hline $\begin{array}{l}\text { Iron (mg) } \\
\text { Zinc (mg) }\end{array}$ & $\begin{array}{c}8^{* *} \\
7.3 / 8.5^{*}\end{array}$ & $\begin{array}{c}8^{*} \\
8.5 \pm 2.5\end{array}$ & $\begin{array}{c}10.2 \pm 3.9 \\
6.5 \pm 2.5\end{array}$ & $\begin{array}{c}8.3 \pm 5.1 \\
0.0427\end{array}$ & $\begin{array}{l}9.4 \pm 3.7 \\
8.1 \pm 3.3\end{array}$ & $\begin{array}{c}11.4 \pm 5.3 \\
9.3 \pm 3.4\end{array}$ & $\begin{array}{l}\text { NS } \\
\text { NS }\end{array}$ & $\begin{array}{l}\text { NS } \\
\text { NS }\end{array}$ & $\begin{array}{c}\text { NS } \\
0.0257\end{array}$ \\
\hline $\begin{array}{l}\text { Copper } \\
\text { (mg) }\end{array}$ & 0.7 & $1 \pm 0.3$ & $0.9 \pm 0.4$ & NS & $0.9 \pm 0.4$ & $1.1 \pm 0.5$ & NS & NS & NS \\
\hline $\begin{array}{l}\text { Manganese } \\
(\mathrm{mg})\end{array}$ & $1.6^{* *} / 2.2$ & $4 \pm 2.2$ & $2.4 \pm 1.6$ & 0.0447 & $3 \pm 2$ & $3.5 \pm 3$ & NS & NS & NS \\
\hline Iodine $(\mu \mathrm{g})$ & 95 & $81.2 \pm 43.8$ & $79.6 \pm 56.5$ & NS & $98.4 \pm 67.1$ & $106.2 \pm 62.9$ & NS & NS & NS \\
\hline
\end{tabular}

IBD—Inflammatory bowel diseases; CG—control group; * girls/boys; ** AI norm; NS—non statistically significant.

\section{Discussion}

Malnutrition is common in children with IBD, especially in patients with CD, both in the exacerbation and in the remission phases of the disease [27]. In patients with UC, malnutrition is relatively less common, although deficiencies may rapidly worsen during exacerbation of the disease [28]. The onset of malnutrition may be influenced by inadequate dietary energy intake, generalized inflammation, and malabsorption [28]. Protein-calorie malnutrition in patients negatively affects not only muscle and respiratory function, but also impairs immune function, including humoral and cellular responses, thus affecting mucosal barrier integrity [29].

In this study, we aimed to analyze the differences between the nutritional patterns of children with IBD and healthy controls and to assess the alterations relative to dietary standards for the Poles. Children with IBD have a high risk of growth delay, and an inadequate intake can make this worse. Similarly, Diederen et al. showed lower energy intake in adolescents with IBD relative to healthy controls [30]. In our study, we also were able to evaluate adequate protein intake in both the control and study groups as well as its normal percentage distribution in the diet. However, we observed an increased intake of animal to plant protein at a ratio of 2:1 in the IBD group. Increased protein intake has also been reported in other studies [31-33]. In the present study, significantly more animal protein was consumed by IBD girls relative to CG girls. It seems that the high intake of animal protein may be related to the maintenance of dietary recommendations and habits from the exacerbation period [33]. In contrast, a study by Diederen et al. found a higher proportion of plant protein intake relative to animal protein in children's diets [30].

A similar percentage distribution of fat intake was shown in a study by Vagianos et al. [31]. Moreover, the study revealed excess intake with respect to saturated fatty acids (SFA), which concerned as much as $61.9 \%$ of girls and $56.3 \%$ of boys in the study group. Similarly, a study by Aghdassi et al. involving patients with CD showed an excessive intake of saturated acids [34]. Meanwhile, FFAs were demonstrated to activate pro-inflammatory TLR4 (toll-like receptor) pathways, enhancing the organism's inflammatory response [35].

In our study, higher carbohydrate intake was observed in the IBD group, especially among girls. This phenomenon also translated into higher assimilable carbohydrate intake in the IBD group relative to CG. The same observations were made in another study [33].

The observed fiber deficiencies indicate that this nutrient is not commonly used in the diets of IBD individuals. However, dietary fiber intake in this study does not differ markedly from the reference standard. A low-fiber diet is often used by patients as a preventive measure. This is explained by the fear of recurrent exacerbation of the disease [36]. Reduced intake of fiber-rich foods was observed in a study by Cohen et al. [37] and in the study by Hartman et al. in which the deficiency of this component was up to 
$44 \%$ [32]. Another study involving children and adolescents with IBD and healthy controls also found similar fiber intake in both groups [36]. Interestingly, there are studies showing a positive effect of fiber intake on lowering the risk of exacerbation of $C D$, but not UC [38].

Regarding fat-soluble vitamins, a drastically low intake of vitamin D was noted in both the study and control groups. Low vitamin D intake is commonly justified by the limited variety of foods in which the vitamin is present in relevant quantities [39]. Inadequate intake of cholecalciferol in the IBD group affected 100\% of girls and $96.9 \%$ of boys. Vitamin D plays a key role in calcium homeostasis and the regulation of blood pressure and electrolytes in the body [40]. It plays a major role in supporting the immune system [40]. A large number of studies show vitamin D deficiency occurs more frequently among patients with CD than UC [41]. Malabsorption disorders associated with IBD might promote reduced vitamin $\mathrm{D}$ absorption through impaired bile salt secretion [42]. It was shown that, in patients with $\mathrm{CD}$ who had lower vitamin $\mathrm{D}$ levels, the disease was of a more severe course [43]. The deficiency of this vitamin has been associated with higher rates of hospitalization and treatment with steroids [44]. Moreover, studies estimated that as many as $77 \%$ of patients with IBD have osteopenia and $12-41 \%$ have osteoporosis [41,45]. The risk of osteoporosis and osteopenia among patients with IBD is also related to insufficient intake and absorption of calcium and potassium, lower body mass index (BMI) and insufficient physical activity, low peak bone mass, and certain medications, especially glucocorticosteroids [46,47]. Adequate calcium intake is crucial due to IBD's association with an increased incidence of osteoporosis, and additionally, during ongoing inflammation, pro-inflammatory cytokines affect the activity of bone cells [42] Due to impaired vitamin $\mathrm{D}$ absorption being associated with the disease, osteomalacia, which is associated with impaired bone mineralization, may also occur [48]. Studies by other researchers have also observed lower dietary calcium intake in patients with IBD $[49,50]$.

Regarding the intake of minerals in this study, there was a significant deficiency of calcium and magnesium consumption in both groups. In addition, a significantly lower intake of this component was shown in IBD boys relative to CG boys. In contrast, mean zinc intake was below the recommended values only in the IBD male group. Inadequate zinc intake maintains inflammation. Adequate levels of this element may reduce the production of pro-inflammatory cytokines and the elevation of mucosal permeability in the course of CD [51]. Magnesium deficiency is also common in patients with IBD, and the deficiency estimates vary between 13-88\% [52]. Insufficient intake of this nutrient might be associated with considerable weakness, muscle cramps, and delayed wound healing, especially in CD [53]. We found in both groups a significant excess of sodium intake standards, which has also been observed by other researchers [54]. In a study in mice, high $\mathrm{NaCl}$ intake was shown to be associated with exacerbation of colon inflammation, suggesting that excess salt intake may exacerbate the disease phenotype [55]. Furthermore, excess dietary sodium can activate macrophages, causing increased inflammatory activity and stimulating pathogenic TH cells [16]. This high sodium intake was mainly due to the consumption of products like cold cuts, cheese, bread, cornflakes, etc. The habit of adding salt (as deliberate salting) was sporadic in this group. In turn, potassium has been shown to exhibit anti-inflammatory effects [56]. Interestingly, inadequate iron intake was also not shown, contrasting with the reports of other researchers [31,57]. Similarly, a study involving patients with CD found deficiencies in components such as calcium, magnesium, zinc, and potassium and, interestingly, higher sodium intake in the female group [58].

\section{Conclusions}

Proper eating habits are crucial for the overall well-being of an organism. Nutrition is a major factor contributing to the course of inflammatory diseases. Therefore, patients diagnosed with IBD should be treated in an interdisciplinary way in cooperation with a doctor and a dietician. Due to the risk of delayed growth and youth development associated with inadequate nutrition, dietary interventions should be introduced early. Moreover, 
nutrition education should be emphasized for a healthy pediatric population. We have not studied the influence of nutritional scales on the course of the disease and therefore cannot recommend a recommended intake of components. However, we would like to highlight the need for supplementation of selected components. We suggest considering supplementation in amounts above $50 \%$ of the requirement for calcium, magnesium, and potassium, as well as vitamin D and folate. Vitamins B1 and B3 and iron should be considered in the amount of about $20 \%$ of the demand. In addition, boys should be supplemented with vitamin $\mathrm{E}$ and zinc.

A major limitation of the study is its relatively small sample size. However, more studies on nutritional assessment in children with IBD are warranted, especially in the context of ethnic diversity. In addition, people on elimination diets and patients with food allergies and severe disease may be at higher risk of deficiencies than our study group. Economic situation was not included due to the reluctance of a significant proportion of patients to answer questions related to social status.

Author Contributions: Conceptualization, J.K. and M.S.; Methodology J.K. and M.S; Visualization J.K. and M.S.; Writing—original draft preparation, J.K. and M.S.; Writing-review and editing, J.K, K.S.-Ż., and M.S.; Project administration, M.S.; Supervision, M.S.; Funding acquisition, M.S., A.K. and D.S. All authors have read and agreed to the published version of the manuscript.

Funding: This research received no external funding.

Institutional Review Board Statement: The study was conducted with the permission of the Bioethics Committee of the Pomeranian Medical University (regulation no. KB-0012/131/18 dated 26 November 2018).

Informed Consent Statement: The study was conducted with the patient's and guardian's written consent.

Data Availability Statement: Data available on request.

Conflicts of Interest: The authors declare no conflict of interest.

\section{References}

1. Alatab, S.; Sepanlou, S.G.; Ikuta, K.; Vahedi, H.; Bisignano, C.; Safiri, S.; Sadeghi, A.; Nixon, M.R.; Abdoli, A.; Abolhassani, H.; et al. The Global, Regional, and National Burden of Inflammatory Bowel Disease in 195 Countries and Territories, 1990-2017: A Systematic Analysis for the Global Burden of Disease Study 2017. Lancet Gastroenterol. Hepatol. 2019, 5, 17-30. [CrossRef]

2. Moazzami, B.; Moazzami, K.; Rezaei, N. Early Onset Inflammatory Bowel Disease: Manifestations, Genetics and Diagnosis. Turk. J. Pediatr. 2019, 61, 637. [CrossRef]

3. Keshteli, A.H.; Madsen, K.L.; Dieleman, L.A. Diet in the Pathogenesis and Management of Ulcerative Colitis; A Review of Randomized Controlled Dietary Interventions. Nutrients 2019, 11, 1498. [CrossRef] [PubMed]

4. Gallo, G.; Kotze, P.G.; Spinelli, A. Surgery in Ulcerative Colitis: When? How? Best Pract. Res. Clin. Gastroenterol. 2018, 32-33, 71-78. [CrossRef]

5. Benchimol, E.I.; Bernstein, C.N.; Bitton, A.; Carroll, M.W.; Singh, H.; Otley, A.R.; Vutcovici, M.; El-Matary, W.; Nguyen, G.C.; Griffiths, A.M.; et al. Trends in Epidemiology of Pediatric Inflammatory Bowel Disease in Canada: Distributed Network Analysis of Multiple Population-Based Provincial Health Administrative Databases. Am. J. Gastroenterol. 2017, 112, 1120-1134. [CrossRef] [PubMed]

6. Rosen, M.J.; Dhawan, A.; Saeed, S.A. Inflammatory Bowel Disease in Children and Adolescents. JAMA Pediatrics 2015, 169, 1053. [CrossRef]

7. Schreiner, P.; Martinho-Grueber, M.; Studerus, D.; Vavricka, S.R.; Tilg, H.; Biedermann, L.; on behalf of Swiss IBDnet. An official working group of the S.S. of G. Nutrition in Inflammatory Bowel Disease. DIG 2020, 101, 120-135. [CrossRef]

8. Gu, P.; Feagins, L.A. Dining With Inflammatory Bowel Disease: A Review of the Literature on Diet in the Pathogenesis and Management of IBD. Inflam. Bowel Dis. 2020, 26, 181-191. [CrossRef]

9. Ananthakrishnan, A.N.; Khalili, H.; Konijeti, G.G.; Higuchi, L.M.; Silva, P.D.; Fuchs, C.S.; Willett, W.C.; Richter, J.M.; Chan, A.T. Long-Term Intake of Dietary Fat and Risk of Ulcerative Colitis and Crohn's Disease. Gut 2014, 63, 776-784. [CrossRef]

10. Tanyaporn, K.; Anil, K. Dietary Management of Pediatric Inflammatory Bowel Disease. J. Med. Food 2019. [CrossRef]

11. Oliveira, S.B.; Monteiro, I.M. Diagnosis and Management of Inflammatory Bowel Disease in Children. BMJ 2017, 357, j2083. [CrossRef] [PubMed]

12. Limdi, J.K. Dietary Practices and Inflammatory Bowel Disease. Indian J. Gastroenterol. 2018, 37, 284-292. [CrossRef] 
13. Bischoff, S.C.; Escher, J.; Hébuterne, X.; Kłęk, S.; Krznaric, Z.; Schneider, S.; Shamir, R.; Stardelova, K.; Wierdsma, N.; Wiskin, A.E.; et al. ESPEN Practical Guideline: Clinical Nutrition in Inflammatory Bowel Disease. Clin. Nutr. 2020, $39,632-653$. [CrossRef] [PubMed]

14. Balestrieri, P.; Ribolsi, M.; Guarino, M.P.L.; Emerenziani, S.; Altomare, A.; Cicala, M. Nutritional Aspects in Inflammatory Bowel Diseases. Nutrients 2020, 12, 372. [CrossRef]

15. Zallot, C.; Quilliot, D.; Chevaux, J.-B.; Peyrin-Biroulet, C.; Guéant-Rodriguez, R.M.; Freling, E.; Collet-Fenetrier, B.; Williet, N.; Ziegler, O.; Bigard, M.-A.; et al. Dietary Beliefs and Behavior among Inflammatory Bowel Disease Patients. Inflam. Bowel Dis. 2013, 19, 66-72. [CrossRef]

16. Owczarek, D.; Rodacki, T.; Domagała-Rodacka, R.; Cibor, D.; Mach, T. Diet and Nutritional Factors in Inflammatory Bowel Diseases. World J. Gastroenterol. 2016, 22, 895-905. [CrossRef]

17. Limdi, J.K.; Aggarwal, D.; McLaughlin, J.T. Dietary Practices and Beliefs in Patients with Inflammatory Bowel Disease. Inflam. Bowel Dis. 2016, 22, 164-170. [CrossRef]

18. Crooks, B.; McLaughlin, J.; Matsuoka, K.; Kobayashi, T.; Yamazaki, H.; Limdi, J.K. The dietary practices and beliefs of people living with inactive ulcerative colitis. Eur. J. Gastroenterol. Hepatol. 2021, 33, 372-379. [CrossRef]

19. Ruemmele, F.M. Role of Diet in Inflammatory Bowel Disease. ANM 2016, 68, 32-41. [CrossRef] [PubMed]

20. Laing, B.B.; Lim, A.G.; Ferguson, L.R. A Personalised Dietary Approach-A Way Forward to Manage Nutrient Deficiency, Effects of the Western Diet, and Food Intolerances in Inflammatory Bowel Disease. Nutrients 2019, 11, 1532. [CrossRef]

21. Kikut, J.; Konecka, N.; Ziętek, M.; Szczuko, M. Inflammatory Bowel Disease Etiology: Current Knowledge. Pteridines 2018, 29, 206-214. [CrossRef]

22. Kikut, J.; Konecka, N.; Ziętek, M.; Kulpa, D.; Szczuko, M. Diet Supporting Therapy for Inflammatory Bowel Diseases. Eur. J. Nutr. 2021, 60, 2275-2291. [CrossRef] [PubMed]

23. Szczuko, M.; Konecka, N.; Kikut, J.; Klimczyk, W. Diet of teenagers with ulcerative colitis, Crohn's disease and coeliac disease versus their blood morphology. Pomeranian J. Life Sci. 2017, 63, 344. [CrossRef]

24. Szponar, L.; Wolnicka, K.; Rychlik, E. Album of Photographs of Food Products and Dishes; National Food and Nutrition Institute: Warsaw, Poland, 2000; ISBN 83-86060-51-4.

25. Jarosz, M.; Rychlik, E.; Stoś, K.; Charzewska, J. Normy Żywienia dla Populacji Polski i ich Zastosowanie; Nutrition Standards for the Polish Population; National Food and Nutrition Institute: Warsaw, Poland, 2020.

26. Overview on Tolerable Upper Intake Levels as Derived by the Scientific Committee on Food (SCF) and the EFSA Panel on Dietetic Products, Nutrition and Allergies (NDA). 2018. Available online: https://www.efsa.europa.eu/sites/default/files/assets/UL_ Summary_tables.pdf (accessed on 14 February 2021).

27. Sila, S.; Trivić, I.; Pavić, A.M.; Niseteo, T.; Kolaček, S.; Hojsak, I. Nutritional Status and Food Intake in Pediatric Patients with Inflammatory Bowel Disease at Diagnosis Significantly Differs from Healthy Controls. Eur. J. Pediatr. 2019, 178, 1519-1527. [CrossRef]

28. Hartman, C.; Eliakim, R.; Shamir, R. Nutritional Status and Nutritional Therapy in Inflammatory Bowel Diseases. World J. Gastroenterol. 2009, 15, 2570-2578. [CrossRef]

29. Marcil, V.; Levy, E.; Amre, D.; Bitton, A.; de Araújo Sant'Anna, A.M.G.; Szilagy, A.; Sinnett, D.; Seidman, E.G. A Cross-Sectional Study on Malnutrition in Inflammatory Bowel Disease: Is There a Difference Based on Pediatric or Adult Age Grouping? Inflamm. Bowel Dis. 2019, 25, 1428-1441. [CrossRef]

30. Diederen, K.; Krom, H.; Koole, J.C.D.; Benninga, M.A.; Kindermann, A. Diet and Anthropometrics of Children With Inflammatory Bowel Disease: A Comparison With the General Population. Inflamm. Bowel Dis. 2018, 24, 1632-1640. [CrossRef]

31. Vagianos, K.; Bector, S.; McConnell, J.; Bernstein, C.N. Nutrition Assessment of Patients with Inflammatory Bowel Disease. J. Parenter. Enter. Nutr. 2007, 31, 311-319. [CrossRef]

32. Hartman, C.; Marderfeld, L.; Davidson, K.; Mozer-Glassberg, Y.; Poraz, I.; Silbermintz, A.; Zevit, N.; Shamir, R. Food Intake Adequacy in Children and Adolescents With Inflammatory Bowel Disease. J. Pediatric Gastroenterol. Nutr. 2016, 63, 437-444. [CrossRef]

33. Opstelten, J.L.; de Vries, J.H.M.; Wools, A.; Siersema, P.D.; Oldenburg, B.; Witteman, B.J.M. Dietary Intake of Patients with Inflammatory Bowel Disease: A Comparison with Individuals from a General Population and Associations with Relapse. Clin. Nutr. 2019, 38, 1892-1898. [CrossRef] [PubMed]

34. Aghdassi, E.; Wendland, B.E.; Stapleton, M.; Raman, M.; Allard, J.P. Adequacy of Nutritional Intake in a Canadian Population of Patients with Crohn's Disease. J. Am. Diet. Assoc. 2007, 107, 1575-1580. [CrossRef]

35. Rocha, D.M.; Caldas, A.P.; Oliveira, L.L.; Bressan, J.; Hermsdorff, H.H. Saturated Fatty Acids Trigger TLR4-Mediated Inflammatory Response. Atherosclerosis 2016, 244, 211-215. [CrossRef]

36. Pituch-Zdanowska, A.; Albrecht, P.; Banasiuk, M.; Banaszkiewicz, A. Dietary Fiber Intake in Children with Inflammatory Bowel Disease. J. Pediatric Gastroenterol. Nutr. 2018, 66, 624. [CrossRef] [PubMed]

37. Cohen, A.B.; Lee, D.; Long, M.D.; Kappelman, M.D.; Martin, C.F.; Sandler, R.S.; Lewis, J.D. Dietary Patterns and Self-Reported Associations of Diet with Symptoms of Inflammatory Bowel Disease. Dig. Dis. Sci. 2013, 58, 1322-1328. [CrossRef] [PubMed]

38. Brotherton, C.S.; Martin, C.A.; Long, M.D.; Kappelman, M.D.; Sandler, R.S. Avoidance of Fiber Is Associated With Greater Risk of Crohn's Disease Flare in a 6-Month Period. Clin. Gastroenterol. Hepatol. 2016, 14, 1130-1136. [CrossRef] [PubMed] 
39. O’Sullivan, F.; Raftery, T.; van Weele, M.; van Geffen, J.; McNamara, D.; O’Morain, C.; Mahmud, N.; Kelly, D.; Healy, M.; O'Sullivan, M.; et al. Sunshine Is an Important Determinant of Vitamin D Status Even Among High-Dose Supplement Users: Secondary Analysis of a Randomized Controlled Trial in Crohn's Disease Patients. Photochem. Photobiol. 2019, 95, 1060-1067. [CrossRef] [PubMed]

40. Sun, J. Vitamin D and Mucosal Immune Function. Curr. Opin. Gastroenterol. 2010, 26, 591-595. [CrossRef]

41. Garg, M.; Lubel, J.S.; Sparrow, M.P.; Holt, S.G.; Gibson, P.R. Review Article: Vitamin D and Inflammatory Bowel DiseaseEstablished Concepts and Future Directions. Aliment. Pharmacol. Ther. 2012, 36, 324-344. [CrossRef]

42. Targownik, L.E.; Bernstein, C.N.; Leslie, W.D. Inflammatory Bowel Disease and the Risk of Osteoporosis and Fracture. Maturitas 2013, 76, 315-319. [CrossRef]

43. Sadeghian, M.; Saneei, P.; Siassi, F.; Esmaillzadeh, A. Vitamin D status in relation to Crohn's disease: Meta-analysis of observational studies. Nutrition 2016, 32, 505-514. [CrossRef]

44. Jadhav, P.; Jiang, Y.; Jarr, K.; Layton, C.; Ashouri, J.F.; Sinha, S.R. Efficacy of Dietary Supplements in Inflammatory Bowel Disease and Related Autoimmune Diseases. Nutrients 2020, 12, 2156. [CrossRef]

45. Donnellan, C.F.; Yann, L.H.; Lal, S. Nutritional Management of Crohn's Disease. Ther. Adv. Gastroenterol. 2013, 6, 231-242. [CrossRef]

46. van Bodegraven, A.A.; Bravenboer, N. Perspective on Skeletal Health in Inflammatory Bowel Disease. Osteoporos. Int. 2020, 31, 637-646. [CrossRef]

47. Hidalgo, D.F.; Boonpheng, B.; Phemister, J.; Hidalgo, J.; Young, M. Inflammatory Bowel Disease and Risk of Osteoporotic Fractures: A Meta-Analysis. Cureus 2019, 11, e5810. [CrossRef] [PubMed]

48. Dedeoglu, M.; Garip, Y.; Bodur, H. Osteomalacia in Crohn's Disease. Arch. Osteoporos. 2014, 9, 1-3. [CrossRef]

49. Vernia, P.; Loizos, P.; Di Giuseppantonio, I.; Amore, B.; Chiappini, A.; Cannizzaro, S. Dietary Calcium Intake in Patients with Inflammatory Bowel Disease. J. Crohn's Colitis 2014, 8, 312-317. [CrossRef] [PubMed]

50. Silvennoinen, J.; Lamberg-Allardt, C.; Kärkkäinen, M.; Niemelä, S.; Lehtola, J. Dietary Calcium Intake and Its Relation to Bone Mineral Density in Patients with Inflammatory Bowel Disease. J. Intern. Med. 1996, 240, 285-292. [CrossRef]

51. Gîlcă-Blanariu, G.-E.; Diaconescu, S.; Ciocoiu, M.; Ștefănescu, G. New Insights into the Role of Trace Elements in IBD. Biomed. Res. Int. 2018, 1813047. [CrossRef]

52. Kruis, W.; Phuong Nguyen, G. Iron Deficiency, Zinc, Magnesium, Vitamin Deficiencies in Crohn's Disease: Substitute or Not? Dig. Dis. 2016, 34, 105-111. [CrossRef]

53. van Langenberg, D.R.; Della Gatta, P.; Warmington, S.A.; Kidgell, D.J.; Gibson, P.R.; Russell, A.P. Objectively Measured Muscle Fatigue in Crohn's Disease: Correlation with Self-Reported Fatigue and Associated Factors for Clinical Application. J. Crohn's Colitis 2014, 8, 137-146. [CrossRef] [PubMed]

54. Hagin, S.; Lobato, D.J.; Sands, B.E.; Korzenik, J.R.; Merrick, M.; Shah, S.A.; Bancroft, B.; Bright, R.; Law, M.; Moniz, H.; et al. Dietary Behaviors in Newly Diagnosed Youth with Inflammatory Bowel Disease. Child. Health Care 2017, 46, 408-420. [CrossRef]

55. Monteleone, I.; Marafini, I.; Dinallo, V.; Di Fusco, D.; Troncone, E.; Zorzi, F.; Laudisi, F.; Monteleone, G. Sodium ChlorideEnriched Diet Enhanced Inflammatory Cytokine Production and Exacerbated Experimental Colitis in Mice. J. Crohn's Colitis 2017, 11, 237-245. [CrossRef]

56. Khalili, H.; Malik, S.; Ananthakrishnan, A.N.; Garber, J.J.; Higuchi, L.M.; Joshi, A.; Peloquin, J.; Richter, J.M.; Stewart, K.O.; Curhan, G.C.; et al. Identification and Characterization of a Novel Association between Dietary Potassium and Risk of Crohn's Disease and Ulcerative Colitis. Front. Immunol. 2016, 7, 554. [CrossRef] [PubMed]

57. Ehrlich, S.; Mark, A.G.; Rinawi, F.; Shamir, R.; Assa, A. Micronutrient Deficiencies in Children with Inflammatory Bowel Diseases. Nutr. Clin. Pract. 2020, 35, 315-322. [CrossRef] [PubMed]

58. Taylor, L.; Almutairdi, A.; Shommu, N.; Fedorak, R.; Ghosh, S.; Reimer, R.A.; Panaccione, R.; Raman, M. Cross-Sectional Analysis of Overall Dietary Intake and Mediterranean Dietary Pattern in Patients with Crohn's Disease. Nutrients 2018, 10, 1761. [CrossRef] [PubMed] 